\title{
Implementasi Model Pembelajaran Problem Based Learning untuk Meningkatkan Penguasaan Defisiensi Nutrisi Tumbuhan pada Mahasiswa Pendidikan Biologi Universitas Pasundan
}

\author{
Andira Rahmawati, Ida Yayu Nurul Hizqiyah \\ Jurusan Pendidikan Biologi, Fakultas Keguruan dan Ilmu Pendidikan, \\ Universitas Pasundan \\ Jl. Tamansari No.6-8, Kota Bandung 60111 Indonesia \\ e-mail: andirarahmawati@unpas.ac.id
}

\begin{abstract}
Abstrak
Rendahnya penguasaan konsep Biologi dapat terjadi karena materi terlalu luas sehingga mahasiswa hanya diberikan konsep saja tanpa memahami konsep tersebut. Salah satu materi yang cukup luas pada matakuliah Fisiologi Tumbuhan adalah mengenai Defisiensi Nutrisi. Metode Problem based learning mampu meningkatkan pemahaman konsep dan dan keterampilan proses pada mahasiswa. Penelitian ini bertujuan untuk mengukur peningkatan penguasaan konsep dan keterampilan proses setelah diimplementasikan model pembelajaran tersebut dibandingkan dengan metode konvensional. Desain yang digunakan dalam penelitian ini adalah pretest-postest control group design dengan sampel penelitian adalah mahasiswa Program Studi Pendidikan Biologi, Fakultas Keguruan dan Ilmu Pendidikan, Universitas Pasundan dengan jumlah 36 orang untuk masing-masing kelas. Hasil penelitian menunjukkan bahwa adanya pengaruh secara nyata dalam aspek pemahaman konsep pada kelas eksperimen dengan kategori tinggi $(\langle\mathrm{g}\rangle=0,70)$ lebih tinggi dibandingkan dengan kelas konvensional yang berkategori rendah $(<\mathrm{g}\rangle=0,39)$. Selain itu, model pembelajaran PBL juga mampu meningkatkan keterampilan proses pada aspek proses pengamatan, pemecahan masalah, penafsiran, dan komunikasi pada kelas eksperimen dibandingkan dengan kelas konvensional.
\end{abstract}

Kata Kunci-Fisiologi Tumbuhan, keterampilan proses, Problem based learning, pemahaman konsep,

\begin{abstract}
The low of understandings in Biology concept can occur because the subtances are too broad so that the students are not understand about these concepts. One of the course in Physiology plant is about Nutrition Deficiency. Problem Based Learning is able to improve the concept understanding and the process skills of student. The aims of this research are to measure the improvement of concept understanding and process skill after the problem based learning (PBL) was implementated and it is compared to convensional method. The design used in this research is the pretestpostest group design with the sample are students of Biology Education Program, Faculty of Teaching and Education, Pasundan University. The number of students are 36 students for each classes. The result showed that PBL affected the concept understanding significantly in experiment class with high category $(\langle\mathrm{g}\rangle=0,7)$ was higher than convensional class with low category $(\langle\mathrm{g}\rangle=0,39)$. Besides that, Problem Based Learning model was also able to improve process skills in observation process, problem solution, interpretation and communication with experiment class was higher than convensional class.
\end{abstract}

Keywords: concept understanding, Plant physiology, Problem based learning, process skill, 


\section{PENDAHULUAN}

Fisiologi Tumbuhan merupakan salah satu mata kuliah wajib yang diajarkan dalam Program Studi Pendidikan Biologi FKIP UNPAS. Tujuan perkuliahan mata kuliah ini adalah agar mahasiswa memahami konsep mengenai fungsi dari alat tubuh pada tumbuhan dan gejala yang ditimbulkan akibat perubahan lingkungan pada tumbuhan. Program perkuliahan ini dilaksanakan dengan mengintegrasikan teori dan praktikum, sehingga diharapkan mampu membantu meningkatkan kemampuan proses pada peserta didik.

Salah satu materi yang cukup banyak pada Fisiologi Tumbuhan adalah konsep kebutuhan mineral untuk tumbuhan. Mineral nutrisi pada tumbuhan merupakan ilmu yang mempelajari mengenai penyerapan, distribusi, metabolisme, dan penyimpanan mineral pada tumbuhan (Taiz dan Zeiger, 2010). Defisiensi nutrisi pada tumbuhan terjadi ketika nutrisi yang dibutuhkan berada di bawah konsentrasi kritis. Gejala defisiensi pada tumbuhan dapat bervariasi dan bergantung pada jenis mineral yang mengalami defisiensi tersebut. Misalnya, defisiensi nitrogen dapat menyebabkan terjadi klorosis pada daun, daun tua gugur lebih cepat, dan tanaman menjadi kerdil.

Pemahaman mengenai defisiensi nutrisi diperlukan untuk memberikan pengetahuan kepada mahasiswa mengenai gejala yang ditimbulkan oleh tumbuhan akibat mengalami defisiensi nutrisi. Pengetahuan ini selanjutnya dapat diterapkan dan diaplikasikan untuk kehidupan sehari-hari. Pemahaman mengenai defisiensi nutrisi akan sulit dilakukan dengan menggunakan media tanah karena jumlah makro dan mikronutrien di dalam tanah tidak diketahui sehingga paramater nutrisi akan sulit untuk diukur. Oleh sebab itu, hidroponik dapat digunakan untuk menganalisis masalah defisiensi nutrisi pada tumbuhan.

Hidroponik merupakan budidaya tanpa menggunakan tanah sebagai media tanaman dengan penambahan nutrisi hara untuk pertumbuhan. Menurut Mas'ud (2009), nutrisi dan media tanam yang berbeda memberikan hasil yang berbeda pada pertumbuhan dan hasil tanaman. Nutrisi yang dibutuhkan tanaman meliputi unsur hara makro dan mikro. Setiap jenis nutrisi hidroponik memiliki komposisi berbeda-beda.
Media dan nutrisi merupakan faktor yang dapat mempengaruhi pertumbuhan dan hasil tanaman secara hidroponik (Perwatasari, et al., 2012).

Pemahaman mengenai gejala defisiensi pada tumbuhan dapat ditingkatkan melalui praktikum defisiensi nutrisi dengan metode hidroponik. Media dan nutrisi pada hidroponik dapat diketahui jumlahnya dan dapat diatur oleh peneliti. Jenis mineral yang ingin diketahui gejala defisiensinya tidak diberikan pada media hidroponik, sehingga tumbuhan tersebut akan mengeluarkan gejala defisiensi mineral tersebut. Permasalahannya, setiap mineral memiliki gejala defisiensi yang berbeda-beda bergantung pada jenisnya, padahal jenis mineral yang dibutuhkan oleh tumbuhan sangat banyak. Oleh sebab itu, penelitian ini diharapkan mampu meningkatkan pemahaman peserta didik mengenai defisiensi nutrisi pada tumbuhan melalui metode hidroponik dengan metode pembelajaran Problem Based Learning.

Pembelajaran secara aktif dilakukan dengan mengolah pengalaman dengan cara mendengar, membaca, menulis, mendiskusikan, merefleksi rangsangan, dan memecahkan masalah (Rusnayati, Prima, 2011). Peserta didik dalam hal ini adalah mahasiswa perlu dibekali dengan kemampuan yang diperlukan untuk memperoleh pengalaman langsung. Kemampuan tersebut dikenal sebagai keterampilan proses atau keterampilan bekerja ilmiah. Upaya pengembangan keterampilan proses dapat dilakukan dengan melakukan proses pembelajaran yang di dalamnya terdapat kegiatan yang berorientasi pada pemecahan masalah.

Jika penyampaian materi hanya dengan melalui metode ceramah saja, peserta didik hanya berperan sebagai penerima materi pelajaran. Padahal seharusnya peserta didik turut mengembangkan keterampilan proses yang dimilikinya sehingga mampu meningkatkan penguasaan konsep mengenai pokok bahasan yang sedang dipelajarinya melalui masalah. Masalah dapat memberikan tantangan kepada peserta didik untuk dapat berpikir lebih dalam.

Belajar berdasarkan masalah atau Problem Based Learning (PBL) adalah suatu proses pembelajaran yang diawali dari masalah-masalah yang ditemukan dalam suatu lingkungan pekerjaan (Pusdiklat, 2004). Dengan pendekatan ini, mahasiswa tidak hanya dijejali dengan konsep-konsep yang bersifat abstrak tetapi juga 
dibekali kemampuan untuk mengaplikasikan konsep yang diterimanya dalam lingkungan nyata (Muhson, 2009).

Dalam PBL, peserta didik diberikan suatu permasalahan. Kemudian secara berkelompok, mereka akan berusaha untuk mencari solusi atas permasalahan tersebut. Untuk mendapatkan solusi, mereka diharapkan secara aktif mencari informasi yang dibutuhkan dari berbagai sumber. Informasi dapat diperoleh dari bahan bacaan, narasumber dan lain sebagainya.

Implementasi strategi pembelajaran berbasis masalah (problem based learning) akan memberikan kontribusi yang cukup signifikan dalam perbaikan proses belajar-mengajar, khususnya dalam menumbuhkembangkan kemampuan berpikir formal siswa, baik dalam meningkatkan kemampuan berpikir hipotetik-deduktif, berpikir proporsional, berpikir kombinatorial, maupun dalam meningkatkan kemampuan berpikir reflektif (Sania, 2007). Pada penelitian ini dilakukan "Implementasi Model Pembelajaran Problem Based Learning untuk meningkatkan Penguasaan Konsep Defisiensi Nutrisi Tumbuhan pada Mahasiswa Pendidikan Biologi Melalui Teknik Hidroponik".

\section{METODE PENELITIAN}

Model pembelajaran yang dikembangkan memiliki karakteristik berbasis kerja ilmiah, menggunakan media pembelajaran yang sederhana, menggunakan metode diskusi dalam membahas hasil percobaan, dan menggunakan asesmen yang sesuai dengan pembelajaran. Penelitian ini terdiri dari tiga tahap yang dilakukan selama 5 bulan, yaitu tahap persiapan, tahap pelaksanaan, dan tahap evaluasi. Desain penelitian yang digunakan adalah "Pretest-postest Control Group Design". Sekelompok kelas dijadikan sampel untuk diberikan perlakuan berupa penggunaan metode pembelajaran PBL, sedangkan kelas lainnya tidak diberikan perlakuan PBL, hanya dengan metode ceramah. Pengaruh penggunaan metode pembelajaran diukur dari perbedaan pengukuran tes awal dan tes akhir.

Tahap persiapan meliputi persiapan bahan dan materi ajar mengenai kaitan defisiensi nutrisi tumbuhan terhadap hidroponik, persiapan mengenai penyusunan asesmen dan evaluasi hasil pembelajaran, menyusun lembar observa- si mahasiswa (modul praktikum), melakukan pre-test kepada mahasiswa, serta persiapan alat dan bahan untuk pelaksanaan hidroponik. Tahap persiapan dilakukan oleh dosen pengampu mata kuliah praktikum dengan asisten yang bersangkutan.

Tahap kedua adalah pelaksanaan hidroponik untuk mengetahui gejala defisiensi nutrisi pada tumbuhan. Pelaksanaan tersebut dilakukan oleh mahasiswa Universitas Pasundan yang sedang mengambil mata kuliah Fisiologi Tumbuhan. Pelaksanaan hidroponik dilakukan selama satu bulan di Laboratorium Biologi Universitas Pasundan. Pelaksanaan hidroponik dilakukan di bawah pengawasan dosen pengampu dan asisten. Penelitian ini dilakukan di Jurusan Pendidikan Biologi, Fakultas Keguruan dan Ilmu Pendidikan, Univrsitas Pasundan. Populasi yang diteliti adalah mahasiswa dengan mata kuliah Fisiologi Tumbuhan yang terdiri dari 2 kelas, masing-masing 36 mahasiswa.

Tahap ketiga adalah evaluasi hasil pembelajaran. Evaluasi hasil pembelajaran dilakukan melalui presentasi pertanggungjawaban mengenai hasil pengamatan yang dilakukan oleh mahasiswa dan pengisian asesmen berupa tes tertulis oleh mahasiswa tersebut. Presentasi dilakukan melalui diskusi antara mahasiswa, dosen, dan asisten. Kegiatan diskusi bertujuan untuk menampung ide, kritik, dan saran untuk memperbaiki kualitas kegiatan pembelajaran. Evaluasi melalui diskusi dan asesmen dilakukan untuk mengetahui pemahaman siswa terhadap pemahaman defisiensi nutrisi pada tumbuhan dan penerapan hidroponik dalam membantu memahami defisiensi nutrisi pada tumbuhan.

\section{HASIL DAN PEMBAHASAN}

Penerapan model Problem Based Learning (PBL) merupakan penelitian tindakan kelas yang dimaksudkan untuk meningkatkan prestasi belajar mahasiswa. Berdasarkan hasil yang diperoleh (lihat Tabel 1), kedua perlakuan yaitu kelas kontrol dan kelas PBL mengalami peningkatan nilai untuk aspek kognitif pada saat posttest dari nilai pretest. Jika diukur dengan gain ternormalisasi antara pretes dan postest, nilai $\mathrm{N}-G$ ain pada pengajaran dengan metode PBL lebih tinggi dibandingkan dengan kelas kontrol. Kelas eksperimen mendapatkan nilai $\mathrm{N}$-Gain dengan kategori tinggi $(\langle\mathrm{g}\rangle=0,7)$ 
untuk aspek kognitif yang lebih tinggi dibandingkan dengan kelas kontrol yang hanya mendapatkan nilai $\mathrm{N}$-Gain dengan kategori sedang $(<\mathrm{g}\rangle=0,39)$.

Tabel 1.

Perbandingan Peningkatan Kognitif berdasarkan Nilai Gain terhadap Nilai Pretes dan Posttest antara kelas Kontrol dan Eksperimen

\begin{tabular}{ccc}
\hline \hline & \multicolumn{2}{c}{ Perlakuan } \\
Jenis Tes & Konrol & PBL \\
\cline { 2 - 3 } & & $71,67 \pm 18,28$ \\
Pretest & $54,17 \pm 11,55$ & $93,61 \pm 5,9$ \\
Posttest & $73,88 \pm 15,72$ & $0,7 \pm 0,33$ \\
$N$-Gain & $0,39 \pm 0,35$ & \\
\hline \hline
\end{tabular}

Data tersebut kemudian diuji normalitas dengan menggunakan uji Kolmogorov-Smirnov. Hasil tersebut menunjukkan (Tabel 2) bahwa data yang dihasilkan bersifat nonparametrik sehingga untuk menentukan perbedaan rataan antara kelas kontrol dan eksperimen dilakukan dengan menggunakan Uji U Mann Whitney. Berdasarkan perhitungan Uji U Mann Whitney, terlihat bahwa nilai Sig. (2-tailed) atau signifikansi untuk uji dua sisi adalah probabilitas di bawah $0,05(0,01<0,05)$. Maka Ho ditolak, atau $\mathrm{N}$-Gain antara kelas kontrol dan kelas eksperimen terdapat perbedaan secara nyata (Tabel 3). Hal ini berarti model pengajaran Problem based Learning dapat meningkatkan pemahaman pada konsep Defisiensi Nutrisi mata kuliah Fisiologi Tumbuhan.

Selain analisis penguasaan konsep, pada penelitian ini juga dilakukan analisis keterampilan proses selama diskusi pada proses pembelajaran antara kelas kontrol dan kelas eksperimen (Gambar 1). Analisis keterampilan proses ini terdiri dari aspek proses pengamatan, berkomunikasi, penafsiran, dan memecahkan masalah (Rusmayanti, Prima; 2011). Berdasarkan hasil pengamatan, kelas eksperimen menghasilkan nilai lebih tinggi pada aspek proses pengamatan, berkomunikasi, penafsiran, dan memecahkan masalah dibandingkan dengan kelas kontrol.
Tabel 2

Hasil Uji Normalitas

\begin{tabular}{lllll} 
& & \multicolumn{3}{c}{ Kolmogorov-Smirnov $^{\text {a }}$} \\
\cline { 3 - 5 } & Perlakuan & Statistic & df & Sig. \\
\hline \multirow{2}{*}{ Pretest } & Eksperimen &, 176 & 36 &, 007 \\
& kontrol &, 419 & 36 &, 000 \\
\hline \multirow{2}{*}{ Posttest } & Eksperimen &, 312 & 36 &, 000 \\
& kontrol &, 236 & 36 &, 000 \\
\hline \multirow{2}{*}{ gain } & Eksperimen &, 201 & 36 &, 001 \\
& kontrol &, 172 & 36 &, 008 \\
\hline
\end{tabular}

${ }^{a}$ Data terdistribusi normal jika nilai sig. $>0,05$

Tabel 3

Hasil Uji Mann-Whitney U

\begin{tabular}{lrrr}
\hline & & & \\
& Pretest & Posttest & \multicolumn{1}{c}{ gain } \\
\hline Mann-Whitney U & 226,000 & 76,000 & 228,000 \\
Wilcoxon W & 691,000 & 541,000 & 693,000 \\
Z & $-3,385$ & $-5,795$ & $-3,323$ \\
Asymp. Sig. (2- & & & \\
tailed) &, 001 &, 000 &, 001 \\
\hline
\end{tabular}

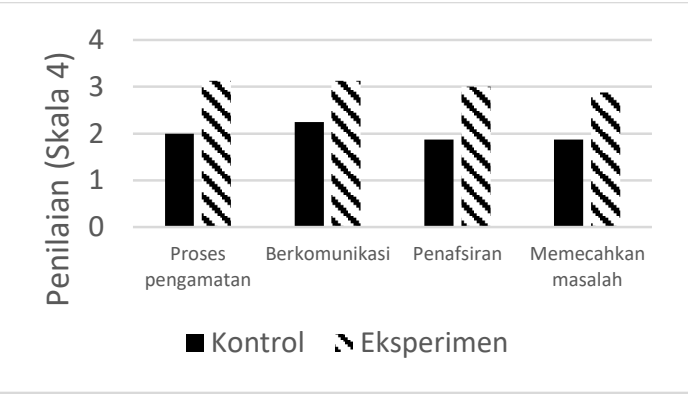

Gambar 1 Grafik penilaian keterampilan proses sains

Model Problem Based Learning (PBL) merupakan model pembelajaran yang melibatkan siswa dengan masalah nyata sehingga mampu meningkatkan motivasi dan rasa ingin tahu dari siswa (Nurhadi dalam Trianto, 2009). PBL juga mampu memberdayakan daya fikir, kreativitas, dan partisipasi siswa dalam pembelajaran. Peningkatan pemahaman konsep dengan metode PBL ditemukan pada beberapa penelitian, antara lain Statistika Lanjut (Muhson, 2009), konsep elastisitas pada Fisika (Rusnayati dan Prima, 2011), pembelajaran fisika pada siswa 
dan SMA (Sadia, 2007).

Pada saat penerapan model pembelajaran PBL, mahasiswa diharapkan mampu menemukan konsep sendiri sehingga mampu memahami konsep tersebut. Siswa bukan saja memperoleh informasi mengenai ilmu pengetahuan tetapi juga membangunkonsep. Dengan pembelajaran PBL diharapkan mampu memberikan kemudahan dalam melakukan proses pembelajaran yang utuh.

Proses pembelajaran Defisiensi nutrisi yang diawali dengan penyajian masalah, kemudian dianalisis oleh mahasiswa dalam kelompok-kelompok untuk memecahkan masalah merupakan kesempatan yang baik dalam mengasah dan melatih keterampilan sains dan kemampuan berpikir. Konsep defisiensi nutrisi dengan melakukan berbagai eksperiman melalui metode hidroponik dapat memberikan pemahaman bagi mahasiswa mengenai proses ilmiah yang terdiri dari merumuskan masalah, merumuskan hipotesis, melakukan eksperimen, menganalisis data, memecahkan masalah tersebut dan membahasnya yang berhubungan dengan data yang ada. Menurut Barraws (Rusnayati dan Prima, 2011), PBL dikembangkan untuk mengembangkan keterampilan berpikir, mengembangkan pengetahuan, dan keterampilan proses. Keterampilan proses dilakukan melalui tindakan secara nyata berdasarkan model Problem Based Learning untuk memecahkan masalah. Pada saat proses dilakukan oleh siswa, maka banyak keterampilan proses yang dilatih kepada siswa.

Jika pada proses pembelajaran konvensional, kesempatan siswa untuk mengasah dan melatih kemampuan tersebut sangat rendah. Kondisi ini yang menyebabkan perbedaan hasil anta kelas kontrol dan kelas eksperimen.

\section{KESIMPULAN}

Model pembelajaran Problem Based Learning dapat meningkatkan pemahaman mahasiswa pada konsep Defisiensi Nutrisi untuk Mata Kuliah Fisiologi Tumbuhan di Program Studi Biologi Universitas Pasundan. Pada proses keterampilan sains, kelas eksperimen menghasilkan nilai lebih tinggi pada aspek proses pengamatan, berkomunikasi, penafsiran, dan memecahkan masalah dibandingkan dengan kelas kontrol.

\section{DAFTAR PUSTAKA}

Aisyah, IS. Nurjhani, M. 2006. 2006. Implementasi Model Pembelajaran Meningkatkan Produksi Pangan melalui Hidroponik. Seminar Nasional MIPA 2006. Yogyakarta, 1 Agustus 2006

Amir, T. 2009. Inovasi Pendidikan melalui Problem Based Learning. Jakarta: Kencana Prenada Media Group

Muhson, A. 2009. Peningkatan Minat Belajar dan Pemahaman Mahasiswa melalui Penerapan Problem Based Learning. Jurnal Pendidikan. 39(2): 171-182

Perwatasari, B., Tripatmasari, M., Wasonowati, C. 2012. Pengaruh Media Tanam dan Nutrisi terhadap Pertumbuhan dan Hasil Tanaman Pakchoi (Brassica juncea L.) dengan sistem hidroponik. Agrovigor. 5 (1): $14-26$

Pusdiklat. 2004 Bahan Pembelajaran Problem Based Learning belajar berbasis masalah. Diambil dari http://www.lrckesehatan.net/ cdroms_htm/pbl/pbl.htm.

Rusnayati, H., Prima, E.C. 2011. Penerapan Model Pembelajaran Problem Based Learning dengan Pendekatan Inkuiri untuk Meningkatkan Keterampilan Proses Sains dan Penguasaan Konsep Elastisitas Pada Siswa SMA. Prosiding Seminar Nasional Penelitian, Pendidikan dan Penerapan MIPA, Universitas Negeri Yogyakarta, 14 Mei 2011

Sadia, I.W. 2007. Pengembangan Kemampuan Berpikir Fornmal Siswa SMA melalui Penerapan Model Pembelajaran Problem Based Learning dan Cycle Learning dalam Pembelajaran Fisika. Jurnal Pendidikan dan Pengajaran UNDIKSHA. 40 (1): 1-20

Taiz, L. dan Zeiger, E. 2010. Plant Physiology. 5th edn. Sunderland: Sinauer Associates

Trianto. 2009. Mendesain Model Pembelajaran Inovatif-Progresif. Jakarta: Prestasi Pustaka Publisher. 